\title{
$\mathrm{SF}_{6}$ 分解生成物が介在した銅点接触子の交流電流 通電特性に関する実験的考察
}

$\begin{array}{lllll}\text { 正員 愛 知 } & \text { 久 } & \text { 史 } & \text { (大同工大) } \\ \text { 正員 } & \text { 佐土根 } & \text { 範 } & \text { 次 } & \text { (大同工大) } \\ \text { 正員 松 } & \text { 村 } & \text { 年 } & \text { 郎 } & \text { (京都大) } \\ \text { 正員 鬼 頭 } & \text { 幸 } & \text { 生 } & \text { (名古屋大) } \\ \text { 正員 向 山 } & & \text { 翼 } & \text { (中部電力) } \\ \text { 正員 高 木 } & & \text { 勲 } & \text { (中部電力) }\end{array}$

\section{Alternating Current Carrying Features of Copper Spot-Contacts with Powder Contamination Produced by Arc Discharges in $\mathrm{SF}_{6} \mathrm{Gas}$ \\ Hisashi Aichi, Member, Hanji Satone, Member (Daido Institute of Technology), Toshiro Matsumura, Member (Kyoto University), Yukio Kito, Member (Nagoya University), Yoku Mukaiyama, Member, Isao Takagi, Member (Chubu Electric Power Co.)}

The gas insulated switchgears are widely adopted in recent electric power substations. The $\mathrm{SF}_{6}$ gas is decomposed by arc discharges and the white powder is produced due to chemical reactions with the contact metal. This kind of undesirable materials are usually absorbed by associated filters. However, if the contacts are contaminated by the resolved gases or the produced powder, they possibly bring about unexpected troubles in the GIS due to abnormal contact resistance. The alternating current carrying features of copper spot-contacts contaminated by the decomposed gas as well as by the accumulated powder between them are experimentally investigated in this paper. When thickness of the powder is about a few layers of particles with diameter of some tens of micro-meter, several hundreds micro-ohm of the contact resistance is obtained with contact load of $9.8 \mathrm{~N}$ at around $100 \mathrm{~A}$. This magnitude decreases to a level of less than $200 \mu \Omega$, when the carrying current is forced to increase to a few thousands amperes. The associated voltage across the contaminated spot-contacts takes always somewhat triangle wave forms low current level and they change into usual sinusoidal ones in a long period current carrying. This aspect is artificially realized in the spot-contacts with other kinds of contaminated powder between them.

\section{キーワード: GIS, 点接触, $\mathrm{SF}_{6}$ ガス，接触抵抗，接触子の劣化， $\mathrm{SF}_{6}$ 分解生成物}

\section{1.まえがき}

近年，電力系統における開閉保護装置には， $\mathrm{SF}_{6} カ ゙$ スを用いた絶縁方式が多くの所で採用されている。こ れらのガス絶縁機器 (Gas Insulated Switchgear) は，本来信頼性が高く，保守・点検も䉮単であるとい われている。しかし，その通電部分仕密閉容器内に収
納されて扔り，そこに異常が発生しても，その発見は 容易でない。更に，万一それが事故に発展した場合に は，その復旧に長時間を要する面もある。従って，事 故にいたる前の段階で異常を発見し，対策を講じて， 事故の発生を未然に防ぐことを目的として，異常予知 に関する各種センサの研究開発が試みられている゙ そのためには，ガス絶縁機器における異常の発生メ力 
ニズムおよび事故への進展過程を学理的に明らかにす る必要がある。それによって，各種センサの開発が促 進されるだけではなく，異常そのものの発生頻度を根 本的に抑え，信頼性をより一層向上させることが可能 となる。

ガス絶縁機器において，過去に事故にまで発展した 異常のなかには，接触子で発生している(2) という事夷 がある一方で， $\mathrm{SF}_{6}$ ガス中における接触子の電気的特 性についてはほとんど研究されていないのが現状であ る。実規模の $\mathrm{SF}_{6}$ ガス遮断器の接触子を模擬し, 棒 状接触子がプラグ（チェーリップ，接触荷重；80〜90 N) に数 $\mathrm{mm}$ 程度挿入された状況で，数分の一秒に わたって接触子間電圧が三角波形になったという報 告 ${ }^{(3)}$ がある。

本諭文は，銅点接触子を対象として， $\mathrm{SF}_{6}$ ガス中で アークなどの放電時に生じる粉末状生成物が接触部分 に介在した接触状態において，交流電流を通電した場 合の接触子間の電圧および電圧波形の推移について， 実験的に検討を加えたものである。

$\mathrm{SF}_{6}$ ガスは，常温では化学的に安定であると共に無 臭，無害のガスである。接触子の開極時に発生するア 一クなどの放電で分解するが, 大部分は元の $\mathrm{SF}_{6}$ 分 子に再結合する特徵がある。ところが，アーク放電な どによって蒸発した電極の金属蒸気などと， $\mathrm{SF}_{6}$ 分解 ガスとの反応によって粉末状の化合物が生じる。

本論文では，この $\mathrm{SF}_{6}$ 分解生成物の粉末が接触子 の接触部分に付着した状態で接触させた場合に現れる 接触子間電圧坮よびその波形の特異現象について考察 した。具体的には，粉末が介在した銅点接触子に数百 $\mathrm{A}$ の正弦波交流電流ちよび数千 A 以上の正弦波状減 衰振動大電流の通電を行い，接触子間の電圧測定なら
びに電压波形を観涀した。なかでも，電圧波形は通電 初期において方形波状を呈し，通電電流の増大や通電 時間の経過と共に三角波状，更には正弦波状に移行す るという現象が見いだされた。更に，この特異な電圧 波形の発生メカ二ズムを検討するために $\mathrm{Al}_{2} \mathrm{O}_{3}, \mathrm{SiO}_{2}$ などの各種粉末を人為的に接触部に介在させ，正弦波 交流電流通電実験を行ったところ，同様の電圧波形の 推移が観測された。これにより，方形波や三角波状の 電圧波形は点接触子間に粉末状の物質が介在している ために生じていることが夷験的に確諗できた。

\section{2. 供試点接触子および $\mathrm{SF}_{6}$ 分解生成物の生成 手順}

奏験に用いた接触子は銅円柱 $(10 \mathrm{~mm} \phi)$ の先端を 半径 $5 \mathrm{~mm}$ 程度の球面に加工したものと, 厚さ $3 \mathrm{~mm}$ の銅平板とを接触させたもので，点接触を構成してい る。両接触子の表面㞲 1500 の研磨紙で研磨してい る。まず, 密閉容器 (容積: 約 $30 l$ ) の中へ図 1 に示 寸上うに球面接触子と平面接触子とを互いに離した状 態で配置し， $\mathrm{SF}_{6}$ ガスを 2 気圧 (絶対值) 充てんす る。(a)図のアーク放電電極（ギャップ: $5 \mathrm{~mm}$ ) は 接触子から $200 \mathrm{~mm}$ 程度離して配固し，接触子とは別 に通電できる。ここに直流 $10 \mathrm{~A}$ のアーク放電を7分 30 秒間継続させる。これは $\mathrm{SF}_{6}$ ガス内ではアーク放 電が不安定であるため, 確実に継続する期間というこ とで設定している。放電後粉末状の $\mathrm{SF}_{6}$ 分解生成物 が霧状に容器内に充満する。こ粉末は白色で時間の 経過とともに沈澱し，平面接触子の表面にも薄くたい 積する。密閉容器内には分解ガスなどを吸着する吸着 剂を設置していないので, 通常のガス絶縁機器に㭁け る場合よりも，多量の分解生成物が生じている。実験

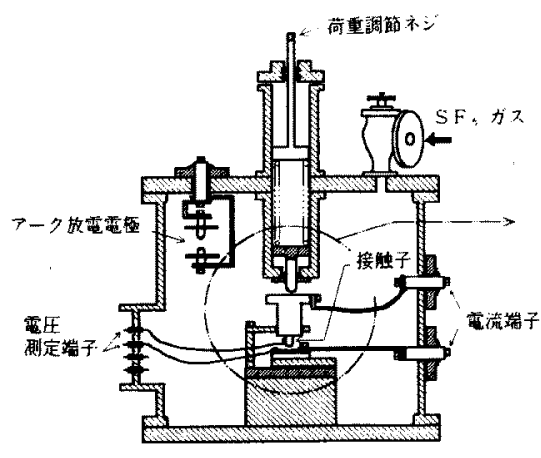

(a) $\mathrm{SF}_{\mathrm{F}}$ ガス密閉突器

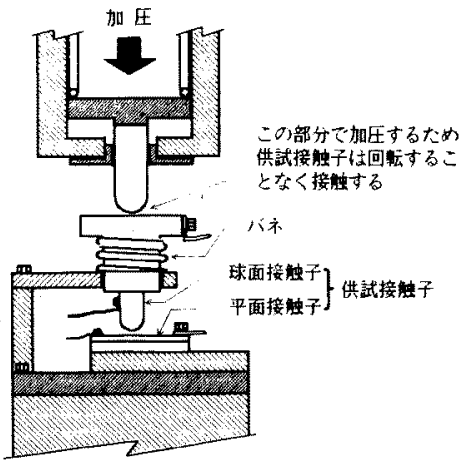

(b) 接鳋子配盢

図 $1 \mathrm{SF}_{6}$ ガス密閉容器, 接触子配置およびアーク放電電極配置

Fig. 1. Arrangement of sample spot-contacts and associated arc discharge electrodes in $\mathrm{SF}_{6}$ gas chamber. 
後約 1 日 $\mathrm{SF}_{6}$ ガス容器内に放置した後,たい積した 生成物を䫓微鏡によって観測したところ，その粒径は 数 $\mu \mathrm{m} \sim$ 数十 $\mu \mathrm{m}$ の範囲にあり, それが $2 \sim 3$ 層たい積 した状態にあることがわかった。

交流通電試験にあたっては，この粉末状生成物が平 面接触子の上にたい積した状態で $\mathrm{SF}_{6}$ ガス容器内に 約 1 日放置した後，(a)図上部の荷重調節ねじを回転 させて球面接触子を平面接触子に押し付けて接触させ ている。接触荷重の調節は密開容器外から自由にでき る構造で, 接触子を大気中に取出すことなく, $\mathrm{SF}_{6}$ ガ 又密閉容器内で通電試験を行うことができる。なお, (b)図の機構により球面接触子は回転せずに平面接触 子に接触する。

\section{3. 正弦波交流電流の連続通電時における接触 子間電圧および接触抵抗}

図 2 に示す通電回路に颃いて, $60 \mathrm{~Hz}, 200 \mathrm{~V}$ の商 用電源加ら変圧器を介して降圧し, 粉末状の $\mathrm{SF}_{6}$ 分 解生成物が介在する銅点接触子に通電する。本実験で は電源設借の都合上, 電流を $150 \sim 600 \mathrm{~A}$ (実効値, 第 4 章を除き以下同様) の範囲に設定している。な お, 接触子間の開放電汪は, 前述の電流範囲で 1 5 $\mathrm{V}$ (実効値)である。

電流を $150 \mathrm{~A}$ から $300 \mathrm{~A}$ 抢よび $450 \mathrm{~A}$ と段階的に 増大させ，それぞれ 5 分間の通電期間において接触子 間の電圧および電流波形を測定している。更に，電流 を $600 \mathrm{~A}$ に增大させ, 約 4 時間の連䋨通電を行って いる。その後, 電流を減少させる過程においても, $450,300,150 \mathrm{~A}$ の各電流值で波形の測定を行って いる。

接触荷重を $9.8 \mathrm{~N}$ に調整した場合の結果の一例を 図 3 杇よび図 4 に示す。前者は電圧拉よび電流波形の 推移であり, 後者は図 3 の各電圧波形加ら求めた波高 值を通電電流実効值に対してプロットしたもので ある。

通電初期の $150 \mathrm{~A}$ から $600 \mathrm{~A}$ まで增大する過程で は接触子間電圧は波高值で $160 \sim 170 \mathrm{mV}$ の間にあり,

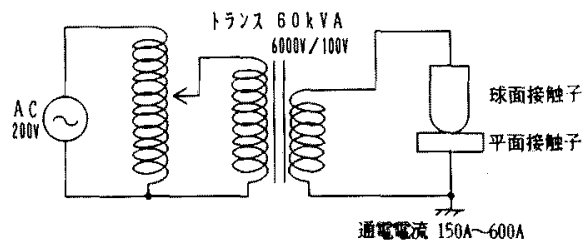

図 2 交流電流通電試験回路

Fig. 2. Circuit arrangement for the alter. nating current applying tests.

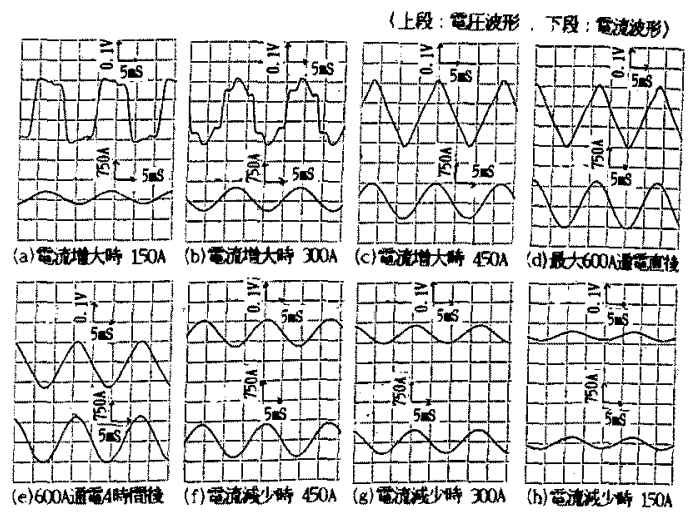

図 $3 \mathrm{SF}_{6}$ 分解生成物が介在した銅点接触子 の交流電流通電時における接触子間電圧波形 の推移（接触荷重：9.8 N)

Fig. 3. Change of voltage waveforms across the copper spot-contacts with powder contamination produced by arc dis. charge in $\mathrm{SF}_{6}$ gas observed under alternating current applying tests (contact load: $9.8 \mathrm{~N})$

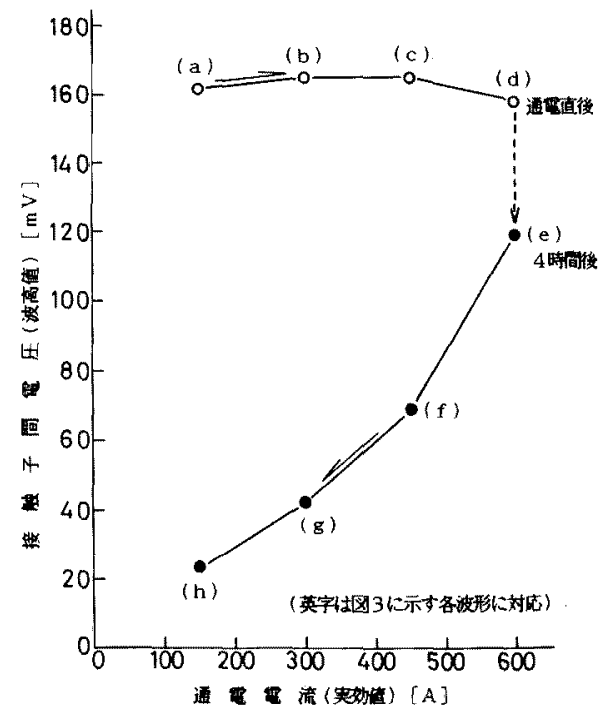

図 $4 \mathrm{SF}_{6}$ 分解生成物が介在した銅点接触子 の交流電流通電時に招ける接触子電王波高値 の推移（接触荷重：9.8 N)

Fig. 4. Voltage drop in peak-value across the powder contaminated spot-contacts during alternating current applying tests (contact load: $9.8 \mathrm{~N}$ ).

電流を增大させる過程においてこの值はほとんど変化 していない。この接触子間電压は銅接触子でいわれて いる軟化電圧 $120 \mathrm{~m} \mathrm{~V}^{(4)}$ 上り $30 \%$ 以上高い。この文献 
の電圧值は直流電流で測定されたもので，直接の比較 はできない。すなわちここでの交流電流による測定 では波形的にも次のような特徵が認められるからであ る。通電当初， $150 \mathrm{~A}$ および $300 \mathrm{~A}$ の各段階で，少な くとも5 分間は電圧波形が方形波に近い状態で持続し ている。しかしながら, 電圧波形は電流の增大と共に 変化し， $450 \mathrm{~A}$ の通電時には三角波状を示している。

更に，600 A まで電流を增大させ， 4 時間の連続通 電後には, 電圧波高值は $158 \mathrm{mV}$ から $118 \mathrm{mV}$ まで低 下し，電圧波形も正弦波状に近い状態となっている。 その後, 電流を減少させたところ, 電圧波高値は通電 電流にほほ比例して低下し, 電圧波形は正弦波状を保 っている。

以上のような電圧波形およびその波高值の推移の特 徵は, 数回の同様の実験において再現性良く観測され ている。

このように実験の再現性は非常に良好なので，電圧 波形が正弦波状ではないが，図3に示した各波形の通 電電流最大瞬時に招ける電圧および電流值から概略の

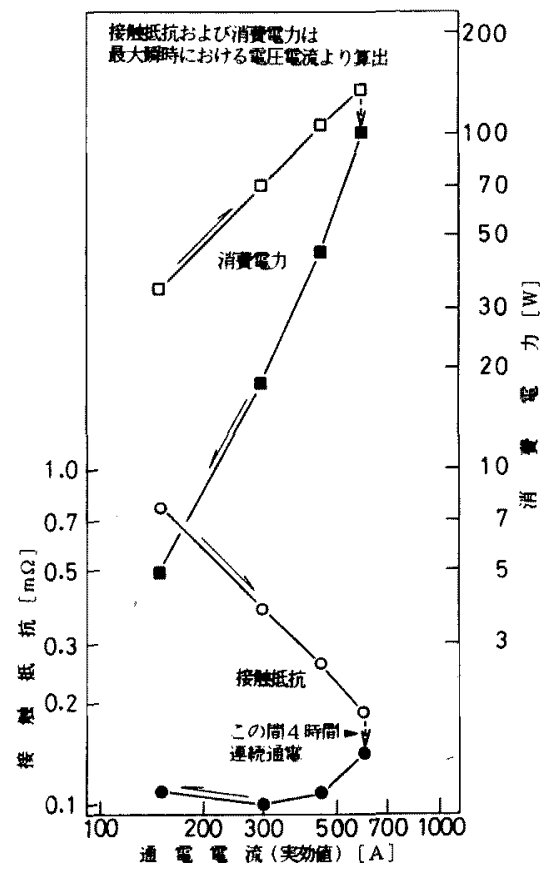

図 $5 \mathrm{SF}_{6}$ 分解生成物が介在した銅点接触子 の交流電流通電時における接触抵抗および

消費電力の変化（接触荷重：9.8 N)

Fig. 5. Contact resistance and power dissipation of the powder contaminated spotcontacts during alternating current applying tests (contact load: $9.8 \mathrm{~N}$ ).
接触抵抗を算定した。また，そのときの消費電力を求 めた。このように算定した接触抵抗值枋よび消費電力 と通電電流との関係を図 5 に示す。図中の○印抢よび 一印は接触抵抗を示し，それぞれ電流增大時および減 少時を表している。また， ロ印㧍よびロ印は消費電力 である。150Aの通電初期に抢いて, 接触抵抗は $0.77 \mathrm{~m} \Omega$ 程度で, 電流の增大に伴って抵抗值は通電 電流にほぼ反比例して低下している。通電電流を 600 $\mathrm{A}$ に增大した直後の接触抵抗は $0.19 \mathrm{~m} \Omega$ まで低下し ており，4時間の連続通電を行った後には, 更に $0.14 \mathrm{~m} \Omega$ まで低下している。その後, 電流を隇少さ せた場合, 接触抵抗はほとんど変化がなく, 最終の $150 \mathrm{~A}$ を通電したときには, $0.1 \mathrm{~m} \Omega$ 程度で, 通電初 期の抵抗值に比べて約 $1 / 8$ となっている。

他方，この実験と同じ接触荷重で金属接触している 純粋の銅接触子において $\mathrm{SF}_{6}$ ガス中で通電試験を行 ったところ, 電圧波形は常に正弦波状であり, その大 きさも $700 \mathrm{~A}$ の通電で $0.1 \mathrm{~V}$ 以上に達し, 通電電流 に比例して增減していることが確認できている。この 場合の接触抵抗は約 $0.14 \mathrm{~m} \Omega て ゙$, 本実験の最終到達 值のレベルにある。このことから 4 時間以上の長時間 を要して金属接触に近い状態になったと思われる。

また, 接触子間における消費電力は通電電流の增大 時において電流にほほ比例する様相を示し, 隇少時に は電流の 2 乗に比例して減少する傾向となっている。 通常, オームの法則に從う金属接触子では，その部分 で消費される電力は電流の 2 乗に比例する。しかしな がら, 本特性では電流の增大時において接触子間の電 圧がほ涩一定であるために, 消費電力の増加割合は比 例的である。反面, 電流の減少時には, ほとんど接触 抵抗が一定のため, 消費電力は電流の 2 乗にほほ比例 する傾向を示している。

これらのことから， $\mathrm{SF}_{6}$ 分解生成物が介在した接触 子に扔いて, 通電電流が小さい場合には, 接触抵抗が 高く, 消費電力も大きくなるので, 接触不良や異常発 熱などの接触子障害を誘発しやすい状況にあるといえ る。

\section{4. 減衰大電流通電時の接触子間電圧波形およ び接触抵抗}

前章では，連続通電できる電源設備の制約から最大 $600 \mathrm{~A}$ (実効値)までの通電試験を行った。更に, 大 電流通電時での特性を調べるために, 図 6 に示す $L C$ 回路を用いて, 正弦波状減衰振動大電流の通電試験を 実施した。電流の周波数は $150 \mathrm{~Hz}$ であり, 約 20 サ イクル前後で電流は減衰消滅する。また, 通電電流の 


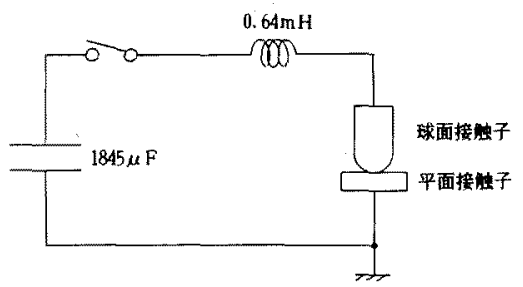

図 6 減衰振動大電流通電試験回路 $(150 \mathrm{~Hz})$

Fig. 6. Circuit arrangement for applying the damped oscillating high current (150 $\mathrm{Hz}$ ) to the copper spot-contacts.

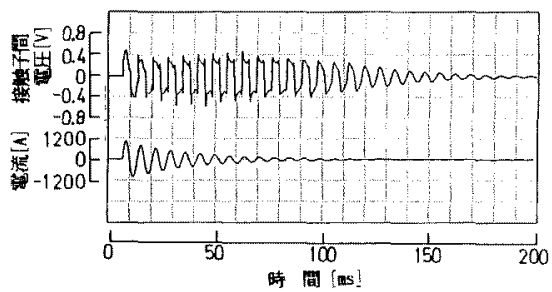

(a) 接紫量 $2 \mathrm{~N}$

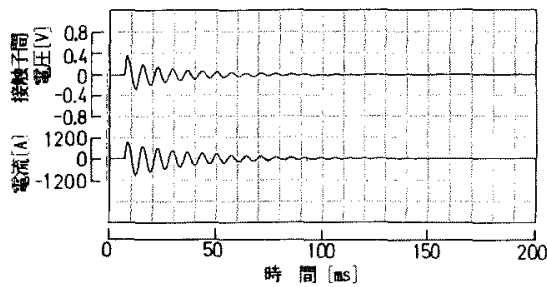

(b) 接标里 $68.6 \mathrm{~N}$

図 $7 \mathrm{SF}_{6}$ 分解生成物が介在した銅点接触子 の減衰振動大電流通電時における接触子間 電圧波形（通電電流：1,000 A)

Fig. 7. Waveforms of the voltage across the powder contaminated spot-contacts observed in damped oscillating high current applying tests (applied current : 1,000 A).

大きさは, 減衰振動電流第一波高値で $500 \sim 5,500 \mathrm{~A}$ の範囲にある。

第 2 章に示した手順で準備した $\mathrm{SF}_{6}$ 分解生成物が 付着した接触子を接触させ, 振動電流の第一波高値を

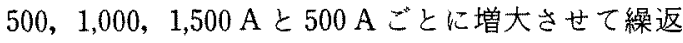
し電流を注入する。な扔，接触荷重は 2，9.8，29.4， $68.6 \mathrm{~N}$ とし，それぞれについて同様の通電試験を行 つている。

$\mathrm{SF}_{6}$ 分解生成物が 2 3 層介在した接触子に第一波 高值が $1,000 \mathrm{~A}$ の減衰電流を通電させたときの接触子 間の電仼波形枋よび電流波形を図 7 に示す。(a)図は 接触荷重が $2 \mathrm{~N}$ の場合の波形である。接触子間の電

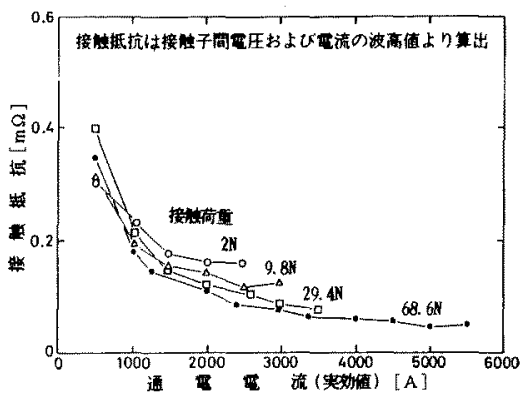

图 $8 \mathrm{SF}_{6}$ 分解生成物が介在した銅点接触子 の減衰振動大電流通電時における 接触抵抗一電流特性

Fig. 8. Contact resistance versus applied current in the powder contaminated spotcontacts in damped oscillating current applying tests.

圧波形は通電初期から方形波状のひずんだ状態となっ ている。また, 電圧の大きさは電流の減衰に比例して 低下せず，ほぼ一定の状態が続いている。12〜14 サ イクル後, 電圧の低下が始まり，それに伴って波形も 三角波状を経由して正弦波状に変化している。(b)図 は $68.6 \mathrm{~N}$ の荷重で接触させた場合の測定結果であ る。電圧の波形は, 通電初期加らほほ正弦波状で, 電 圧の大ききも電流の減衰と共に低下している。

なお，比較のために， $\mathrm{SF}_{6}$ 分解生成物が介在してい ない銅の金属接触の場合についても同様の測定を行っ たところ，接触子間電珐の波形は正弦波状であり，方 形波状や三角波状の波形が現われることはなかった。 また，電圧の大きさも電流の減衰に比例して低下 した。

以上の観測結果から， $\mathrm{SF}_{6}$ 分解生成物の介在した接 触状態に扔いて正弦波状減衰振動大電流の通電時に点 接触子間に現れる電圧波形には次の二つの特徵のある ことが明らかとなった。

（1）接触荷重が低く，しかも通電電流が比較的小 さい場合には, 接触子間の電圧波形は方形波状を呈す る。

（2）接触荷重が数十 $\mathrm{N}$ と高い場合, あるいは数 干Aという大電流を通電した場合には，通常の金属 接触している点接触子と同様に, 正弦波状の電圧波形 が観測される。

図 8 は接触部分に $\mathrm{SF}_{6}$ 分解生成物が介在した点接 触子を $2 ， 9.8 ， 29.4 ， 68.6 \mathrm{~N}$ の各接触荷重で加圧接 触させたそれぞれの試料について, 減衰振動電流を通 電したときの通電電流と接触抵抗との関係を示したも のである。接触抵抗の值は; 前述の電圧, 電流波形を 


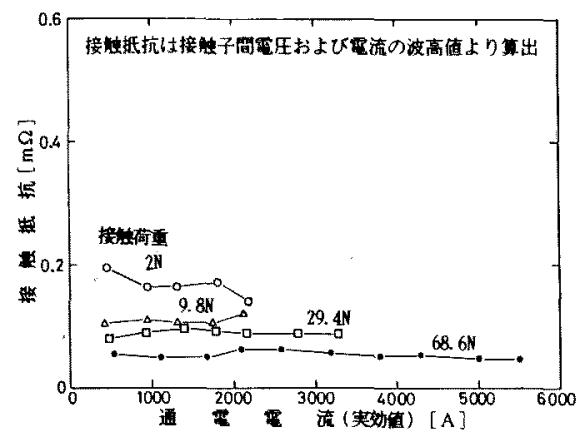

図 9 金属接触した銅点接触子の振動大電流 通電時における接触抵抗一電流特性

Fig. 9. Contact resistance versus applied current characteristics of the normal copper spot-contacts observed in damped oscillating current applying tests.

用いて，電流の第一波高値とその時点の電圧値から算 出している。各接触子に $500 \mathrm{~A}$ (波高値) を通電した 場合の接触抵抗は, $0.3 \sim 0.4 \mathrm{~m} \Omega$ の範国にある。接 触抵抗は, 通電電流の增大に伴って低下し, $2,000 \mathrm{~A}$ 以上の通電状態では, 次に示す金属接触している純粋 の銅点接触子の接触抵抗と同程度の大きさにまで低下 している。

他方, $\mathrm{SF}_{6}$ 分解生成物が介在していない場合とし て，金属接触させな純粋の銅点接触子に扔ける特性を 図 9 に示す。 $500 \mathrm{~A}$ を通電したときの接触抵抗は, 2 $\mathrm{N}$ の接触荷重で, $0.2 \mathrm{~m} \Omega$ 程度にあり, $68.6 \mathrm{~N}$ の荷

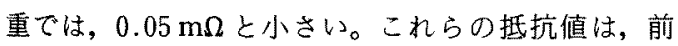
述図 8 で示した $\mathrm{SF}_{6}$ 分解生成物が介在した場合の接 触抵抗に対して，1/2〜1/5 程度である。また，通電 電流が増大しても接触抵抗は汪とんど変化していない と共に, 接螌荷重の高い汪ど抵抗值が全体的に低い傾 向となっている。

以上のことから, $\mathrm{SF}_{6}$ 分解生成物が介在した場合の 銅点接触子の接触抵抗は, 通電電流が小さい場合には 高いが，電流の増大と共に抵抗值は低下する傾向にあ る。これは, $\mathrm{SF}_{6}$ 分解生成物が大電流の通電によって 破壊され，それにより接触子が金属接触状態になるた めと推察される。

\section{5. 各種粉末を介在させた銅点接触子の端子間 電圧波形}

図3に示すように， $\mathrm{SF}_{6}$ 分解生成物が介在した銅点 接触子に正弦波状交流電流を通電した場合, 端子間に 現れる電圧波形は方形波状や三角波状を呈することが ある。この場合, 粉末状物質が接触子間に介在するこ
とが特徵である。そこで別種の粉末を人為的に接触子 間に介在させ，これを実駼的に検証することとした。

$\mathrm{SF}_{6}$ 分解生成物と同程度の粒径（数 $\mu \mathrm{m} \sim$ 数十 $\mu \mathrm{m}$ ） の各種の粉末を銅接触子間に数層程度介在させて，第 3 章と同様の通電実験を行い, 端子間の電圧波形を観 测する。粉末としては, 酸化物として $\mathrm{Al}_{2} \mathrm{O}_{3}, \mathrm{SiO}_{2}$, $\mathrm{CdO}, \mathrm{PbO}$, 他の化合物として $\mathrm{BaSO}_{4}, \mathrm{Mg}(\mathrm{OH})_{2}$, および他種金属として $\mathrm{Zn} の 7$ 種類を用意した。

第 2 章図 1 に示したと同様に球面対平面の点接触を 対象として，平面接触子の上に各種粉末を $180 \mu \mathrm{m}$ メ ッシュのふるいを通して 2 3 粒子層に薄くたい積さ せる。その上から荷重をかけて球面接触子を接触させ 大気中で通電試験を行う。図 2 の通電回路を用いて, 開放電圧 $1 \mathrm{~V}$ (150 A 通電が可能) の電圧を接触子間 に印加した状態で，通電が得られるまで接触荷重を增 加させる。通電状態となった後, 電流を実効值 150 , $300,600 \mathrm{~A}$ と段階的に増大させ，各電流值に扔いて 5 分間通電している。

各粉末についてそれぞれ数回の通電試験を行い，端 子間の電圧波形を観測している。その結果を表 1 にま とめて示す。阔表には，比較のために $\mathrm{SF}_{6}$ 分解生成 物をたい積させた接触子についての測定結果も8とし て併記した。

同表には, 最上段から, 粉末の種類, 粒径, 試験回 数，そのう方荷重 $68.6 \mathrm{~N}$ までの範囲で導通の得られ た回数およびその場合の観測波形例を示している。導 通の回数は，(1) $\mathrm{Al}_{2} \mathrm{O}_{3}$ を用いた試験では 6 回の試験 のうち 3 回, (2)の $\mathrm{SiO}_{2}$ では 4 回の試験で 3 回などと なっている。

波形例の欄には, 導通が得られたときの接触荷重と 150，300，600Aの通電中における端子間の電圧波形 を示す。また，各波形の下に，電流の波高值とそのと きの電圧值とから求めた接触抵抗の值を併記してあ る。なお， $150 \mathrm{~A}$ を通電した場合には 5 分間の通電中 に波形が変化する場合があったので, 通電初期および 変化後の波形を示している。 $300 \mathrm{~A}$ および $600 \mathrm{~A}$ の通 電期間中（ 5 分間）に扔いては, 波形の大きな経時変 化は認められなかったので，通電初期のものを示して いる。

端子間の電压波形は，(7)の $\mathrm{Zn}$ を除く6 種類の粉末 拈いて，150 A の通電初期には方形波状である。時間 の経過抽よび電流の増大に伴い, 波形は三角波状に変 化している。これは, 前述の図 3, 図 9 および表 1 (8) に示すように, $\mathrm{SF}_{6}$ 分解生成物が介在した接触子にお いて観測された結果とよく一致している。また，Zn の場合, 端子間の電圧波形は, 電流値および通電時間 
表 1 各種粉末が介在した銅点接触子の交流電流通電時に扔ける端子間電圧波形の変化

Table 1. Transitons of voltage waveforms across the copper spot-cotacts with different powders contamination observed in alternating current applying tests.

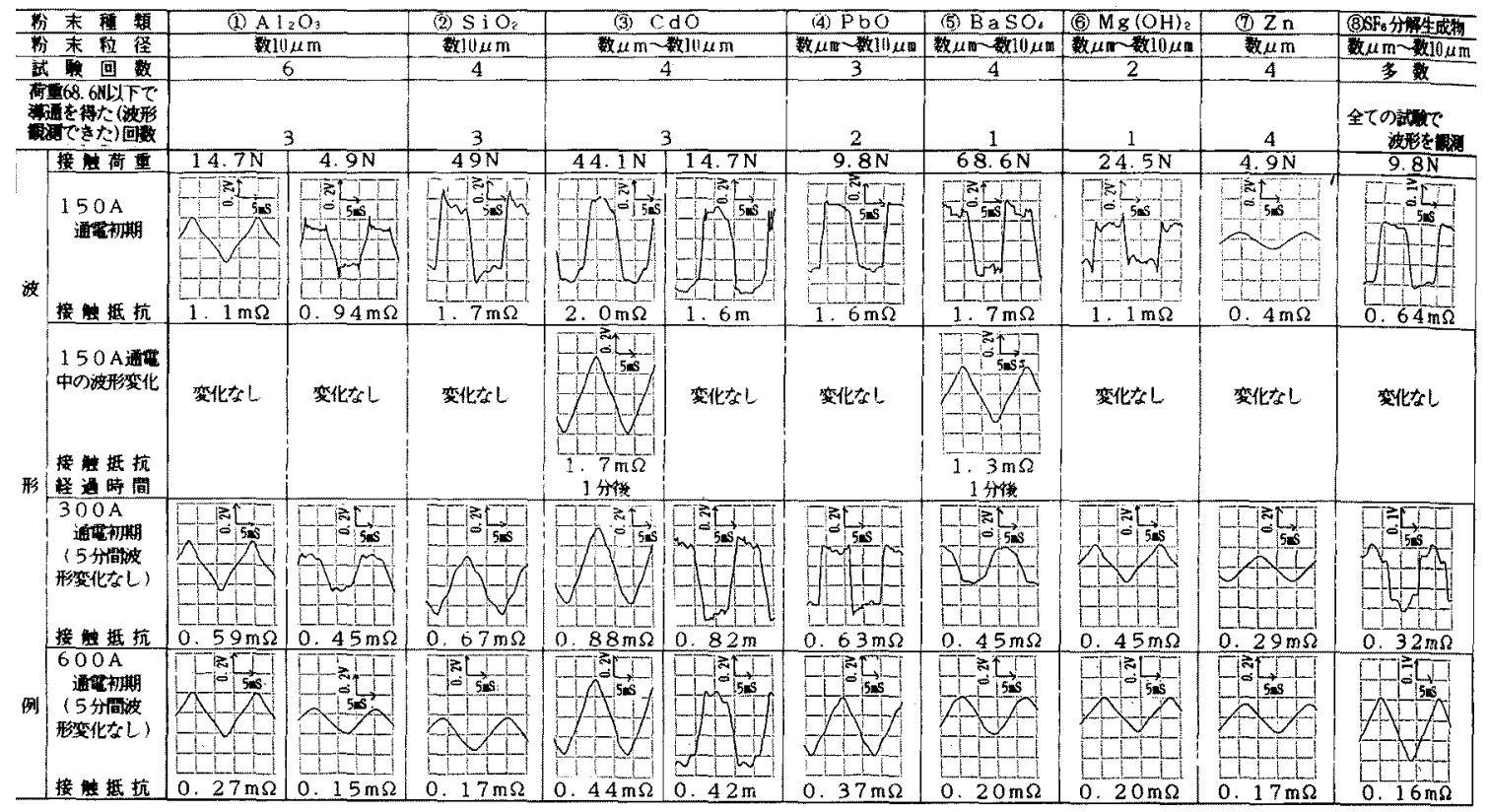

の経過によらず，ほぼ正弦波状である。これは，Zn が金属粉末であるので，接触子が金属接触しているた めと考えられる。

第 1 章にあげた実規模接触子でも数分の一秒のオ一 ダの過渡的期間に三角波形が観測されたと指摘されて いるが，本実験では数時間にわたって方形波や三角波 が持繶しており，しかも途中で波形が変わるなどの特 徵が見られた。これは，SF6 分解生成物が介在した接 触子において, 正弦波状の交流電流あるいは振動電流 の通電時に端子間の電圧波形が方形波状あるいは三角 波状を呈するのは，粉末状の非金属 $\mathrm{SF}_{6}$ 分解生成物 が接触子間に介在することに起因していると考えられ るが，物理的機構については明確ではない。この実騟 では発光や音は観測されていない。

\section{6.むすび}

本論文では，SF6 ガス中に発生させたアーク放電に よって生成される粉末状の $\mathrm{SF}_{6}$ 分解生成物が接触子 間に介在した場合について，交流電流通電時の接触子 間電圧の実験的解析を試みた。数百 $\mathrm{A}$ 程度の正弦波 交流電流および数千 $\mathrm{A}$ 程度の正弦波状減衰振動電流 の通電試験の結果，次のことが明らかとなった。
（1）粒径数十 $\mu \mathrm{m}$ 程度の $\mathrm{SF}_{6}$ 分解生成物力゙数層介 在した銅点接触子において，接触荷重 $9.8 \mathrm{~N}$ で加圧 した状態で，数百 A以下の比較的小電流を通電した ときの接触抵抗は $0.3 \sim 0.8 \mathrm{~m} \Omega$ と高い。通電電流の 増大に伴って接触抵抗は低下し，数干A以上の通電 状態では $0.2 \mathrm{~m} \Omega$ 以下となる。これは，大電流の通電 によって $\mathrm{SF}_{6}$ 分解生成物が破壊されやすいことを示 している。しかしながら，接触荷重が低く，小電流通 電の状態では，行解生成物による接触不良や異常過熱 等の接触子障害を誘発する危険性がある。

（2）接触子に数百 $\mathrm{A}$ 以下O正弦波交流電流の通 電時の数時間にわたって，接触子間の電圧波形におい て方形波状や三角波状を呈する現象がある。ほとんど の場合，方形波から三角波そして正弦波へと移行卞る。

(3) $\mathrm{SiO}_{2}$ などの酸化物, $\mathrm{BaSO}_{4}$ などの化合物の 粉末を接触子間に介在させた場合にも，接触子間の電 圧波形に方形波状や三角波状が現れることを確認し た。従って，SF 6 分解生成物が介在した接触子におい て見られる電圧波形のひずみ現象は，その生成物が導 電性の低い粉末であることに起因するものであると推 測される。

(平成 2 年 5 月 25 日受付，同 2 年 11 月 20 日再受付) 


\section{文献}

（1）藤波, 他：「磁界七ンサに上るGIS 導体接触不良診断手法 の開発」, 電気学全開閉保護装置研資, SPD-88-33 (昭 63)

（2）仙石 他：「遮断器の信頼性と診断技術の現状一遮断に関寸 万信頼性と䛦断技術一」, 同上, SPD-87-2 (昭 62)

(3) Y. Ohshita, et al.: "A Diagnostic Technique to Detect Abnormal Conditions of Contacts Measuring Vibrations in Metal Enclosures of Gas Insulated Switchgear". IEEE 89, WM 073-8 PWRD, New York (1989)

（4）土屋：電気接点技術, p. 47 (昭 57) 総合䉓子出版社

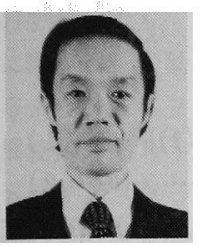

\section{愛 知 久 史 (正員)}

昭和 21 年 6 月 15 日生。 44 年 3 月大同工業大学工学部電気工学科卒 業。同年 4 月大同工業大学技手, 45 年 4 月同大学助手, 60 年講師, 現 在に至る。主として, 電力用開閉機器の接触機構に関 する研究に従事。

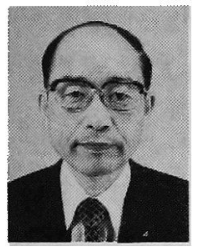

\section{佐土根 範 次 (正員)}

大正 9 年 9 月 29 日生。昭和 16 年 3 月浜松高等工業学校電気科卒業。 工業技術院電気試験所（現電子技術 総合研究所）大阪支所, 松下電気産 業(株)照明研究所, 各研究室長を経て, 53 年 4 月大 同工業大学教授, 現在に至る。光, 熱放射, 赤外, 紫 外, 放射線温度など電気応用計測, 省エネルギー照明 など電気応用の研究に従事。工学博士。39 年照明学 会賞受賞。44, 45 年照明学会編集理事, 56 年照明学 会東海支部評議員, 空気調和衛生工学会, 日本色彩学 会会員。

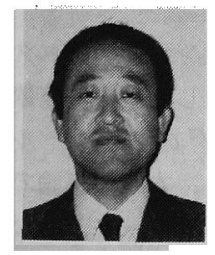

\section{松 村 年 郎 (正員)}

昭和 26 年 5 月 1 日生。 54 年 3 月 名古屋大学大学院工学研究科博士課 程修了。同年 4 月同大学助手, 62 年 2 月同講師, 平成元年 3 月京都大
学講師, 現在に至る。工学博士。主として, 大電流遮 断アークの研究, 超電導システムに関する研究, 回転 機空げき磁束の挙動に関する研究に従事。

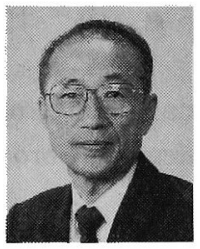

\section{鬼頭幸生（正員）}

昭和 8 年 3 月 12 日生。 35 年 3 月 名古屋大学大学院工学研究科電気工 学専攻博士課程修了。同年 4 月同大 学助手。36 年同講師, 37 年同助教 授, 49 年同教授, 現在に至る。工学博士。大電流遮 断現象の研究, 冬季雷の研究, 超電導送電システムの 研究および電力分野におけるエキスパートシステムの 開発研究に従事。電気学会調査理事 (昭 63 年度 平 元年度)。 47 年電気学会諭文賞, 平 2 年同電力賞授 賞。応用物理学会, 日本分光学会, IEEE 会員。

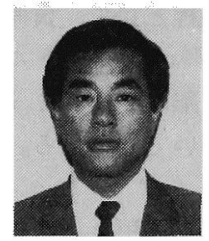

\section{向井翼 (正員)}

昭和 17 年 10 月 6 日生。 40 年 3 月北海道大学工学部電気工学科卒 業。同年 4 月中部電力 (株) 入社。電 力設備の研究開発に従事。平成元年 7 月同社工務部次長。

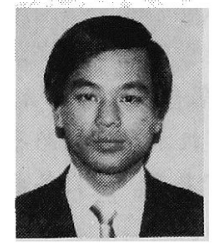

\section{高 木 勲（正員）}

昭和 32 年 5 月 5 日生。 55 年 3 月 名古屋大学工学部電気学科卒業。同 年 4 月中部電力 (株) 入社。電力設備 の保守, 運転および研究開発に従 事。 61 年 8 月, 同社工務部技術課, 平成 2 年 7 月同 社豊橋電力所勤務。平成 2 年進歩賞受賞。 